\title{
Study of Some Virulence Factor and Detection of Sortase Enzymes A and Cov R/S of Streptococcus Agalactiae by PCR
}

\author{
Nktel Faaz Nassir AL-Saad \\ Al-Qasim Green University , College of Biotechnology \\ n.faaz@yahoo.com
}

Received:-25/1/2017

Accepted:-12/3/2017

\begin{abstract}
:
This study included 100 pregnant and non-pregnant patients infected with vaginitis who were attended the hospital of maternity and children in Babylon province from January to May 2016. Only 25 isolates of Streptococcus agalactiae (GBS) were isolates.

Sortase A enzyme were detected by using specific primer for PCR techniques and also found that all GBS strain have sortase A enzyme, so this enzyme is consider as housekeeping enzyme.

Moreover, specific PCR primers were used for detection of CovR/S enzymes. It was found that CovR/S was observed only in tow isolates of Group B streptococcus GBS strains.

The isolates have been examined to chick their ability to produce colonization factor antigens type1 (CFA/I) . The finding showed that they revealed the ability to produce CFA/1 in the existence of Dmannose and Vancomysin. Also, the isolates, have the ability to produce CFA/1 in the existence of Dmannose without Vancomysin.

The capability of GBS isolates to produce Hemolysin in the presence of Vancomysin were studied. It was found that there was no hemolysis in the presence of Vancomysin (except for one isolate), this will give good sign for this antibiotic to reduce the ability of this bacteria to obtain iron from environment.
\end{abstract}

Physiology Classification QR1-502-75-9905 


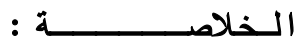

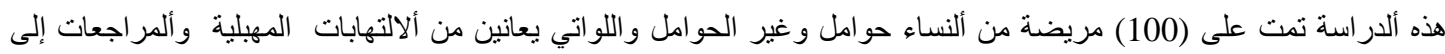

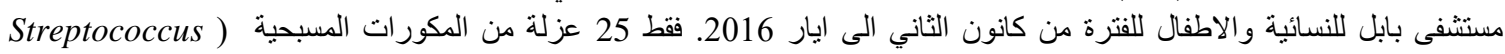
agalactiae

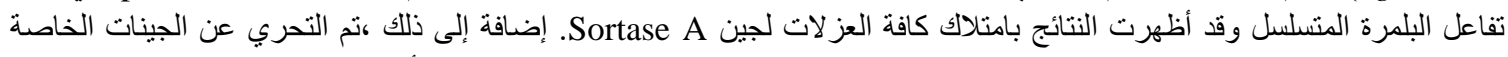

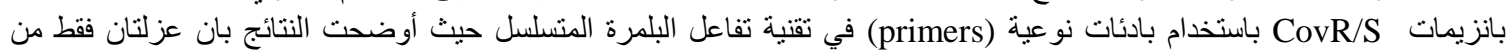
Group B streptococcus GBS حيث اظهرت النتائج بان البكتريا لها القدرة على انتاج هذا العامل بوجود Colonization factor antigen(CFA/I)

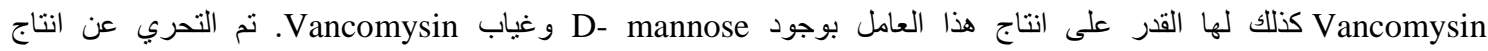

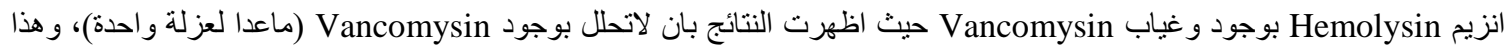
يعطي إثارة جيدة لهذا المضاد الحيوي بقدرته على اختزال قابلية هذة البكتريا للحصول على الحديد من البيئة المحيطه.

Key Words: Streptococcus agalactiae, Sortase Enzymes A and Cov R/S. 
Gram-positive encapsulated bacterium that described as a zoonotic organism. The main site for colonization of these bacteria are rectum and the vagina. Furthermore, it has been proved that the colonization in these areas is considered as a risk factor for pregnant and newborn further infection [1].

The infection by GBS in pregnant women causes bacteremia, endometritis and chorioamnionitis. women colonized with GBS in the period of pregnancy are at an increasing risk of premature delivery and stillbirths [2]. In non pregnant women GBS can lead to soft tissue and skin infections, infection of joints, UTI and a wide range of other presentation such as: liver diseases, DM, cardiovascular diseases and cancers [2].

One of the most virulence factors for Streptococcus agalactiae that mediates in wall anchoring are A,B \& C sortase enzymes which have a major role in some diseases like meningitis and neonatal sepsis [3]. Among these enzymes are sortase A which is considered as a housekeeping sortases and was shown experimentally to fix a lot of surface proteins [4].

The Cov $S / R$ system (Control of virulence Sensors and Regulators) that expression from many GBS virulence genes that leads to an increase or decrease of virulence in this bacteria [5].

On the other hand the major virulence enzyme associated with GBS so fare identified are surface or secreted components, involving colonization factor antigen and $\beta$ - hemolysin which promote enhancing bacterial pathogenecity [6].

\section{Aims of the study:}

This studies aimed to Investigate from some virulence factor such as colonization factor antigen, hemolysin, sortase A enzyme and COV R/S.

\section{Patients and Methods:}

Sample collection:
This study included 25 GBS isolated from 100 pregnant and non-pregnant women patients infected with vaginitis who were admitted to hospital of maternity and children in Babylon from January to May 2016.

In order to reach the final identification, the isolates of GBS were tested by staining with Gram stain and traditional biochemical test [7],[8].

\section{Detection of Sortase enzymes (A) and CovR/S by PCR:}

Bacterial DNA extract was used in specific polymerase chain reactions as a template for the detection of virulence genes StrA and CovR/S. Bacterial DNA were purified by using the wizard minipreps DNA Kit (Geneaid-USA). A primer was used for the amplification of a fragment genes according to the references mentioned in tables (1) and (2).

Table (1) Sequences of primers and PCR conditions to detect genes of Sortase.

\begin{tabular}{|c|c|c|c|c|}
\hline Genes & $\begin{array}{c}\text { Sequences } \\
\text { of primers } \\
\left(5^{\prime}-3^{\prime}\right)\end{array}$ & $\begin{array}{l}\text { Size of } \\
\text { product } \\
\text { bp }\end{array}$ & $\begin{array}{c}\text { conditions } \\
\text { of PCR }\end{array}$ & references \\
\hline 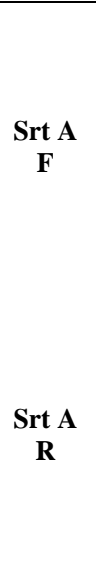 & $\begin{array}{c}\text { TACTT } \\
\text { CCAAT } \\
\text { CCAATG } \\
\text { CATCTG } \\
\text { CTCAAA } \\
\text { CGAAAT } \\
\text { CACATA }\end{array}$ & 500 & $\begin{array}{c}94^{\circ} \mathrm{C} \\
3 \mathrm{~min} 1 \mathrm{x} \\
94^{\circ} \mathrm{C} \\
2 \mathrm{~min} \\
\\
63^{\circ} \mathrm{C} \\
1 \mathrm{~min} 28 \mathrm{x} \\
72^{\circ} \mathrm{C} \\
1 \mathrm{~min} \\
\end{array}$ & $\begin{array}{l}\text { Khare, } \\
\text { et.al.,2010 }\end{array}$ \\
\hline
\end{tabular}

Table (2) Sequences of primers and PCR conditions to detect genes of $\mathrm{Cov} R / \mathrm{S}$. 


\section{Detection of amplified DNA products by using agarose gel electrophoresis:}

Amplified production of PCR was confirmed by agarose gel electrophoresis [9]. Agarose gel was prepared by dissolving $2 \mathrm{gm}$ of agarose powder in $100 \mathrm{ml}$ of TBE buffer $(\mathrm{pH}: 8)$ in boiling water bath, allowed to cool to $50^{\circ} \mathrm{C}$ and ethidium bromide at the concentration of $0.5 \mathrm{mg} / \mathrm{ml}$ was added.

The comb was fixed at one end of the tray for making wells used for loading DNA sample. The agarose was powered gently into the tray, and allowed to solidify at room temperature for $30 \mathrm{~min}$. The comb was then removed gently from the tray.

The tray was fixed in an electrophoresis chamber which was filled with TBE buffer covered the surface of the gel. $5 \mu 1$ of DNA sample was transferred into the assigned wells in agarose gel, and in one well we put the $5 \mu \mathrm{l}$ DNA ladder mixed with $1 \mu \mathrm{l}$ of loading buffer.

\section{Colonization Factor Antigen (CFA/I):}

After culturing the organism on Tryptic soy agar and incubating it at $37^{\circ} \mathrm{C}$ for $24 \mathrm{hrs}$, the agglutination between RBC and bacteria occurs in the existence of $\mathrm{D}$ mannose [10].

\section{Haemolysin production:}

Hemolysin production was done by inoculating a BAM (blood agar medium) with isolated bacteria at $37^{\circ} \mathrm{C}$ for $24 \mathrm{hrs}$. Streptococcus agalactiae form a clear area around the colonies, that refer to complete hemolysis (ß- hemolysis) [11].

\section{Results and Discussion}

\section{Bacterial isolates:}

Only 25 isolates of GBS were obtained in this study which were isolated from patients (pregnant and non-pregnant women). All isolates were cultured in

\begin{tabular}{|c|c|c|c|c|}
\hline Genes & $\begin{array}{c}\text { Sequences } \\
\text { Of } \\
\text { primers } \\
\left(5^{\prime}-3^{\prime}\right)\end{array}$ & $\begin{array}{c}\text { Size of } \\
\text { product } \\
\text { bp }\end{array}$ & $\begin{array}{c}\text { conditions } \\
\text { of PCR }\end{array}$ & references \\
\hline $\begin{array}{c}\text { CovR/S } \\
\text { F }\end{array}$ & $\begin{array}{c}\text { GCGTC } \\
\text { TAGAG } \\
\text { AATAA } \\
\text { GAAGG } \\
\text { TTGGT } \\
\text { GTAGA } \\
\text { TGGG } \\
\\
\text { CGCGG } \\
\text { ATTCG } \\
\text { AAGCG } \\
\text { CCTCT } \\
\text { CTTAT } \\
\text { CACCTC }\end{array}$ & 2,286 & $\begin{array}{c}95^{\circ} \mathrm{C} \\
2.5 \mathrm{~min} \\
1 \mathrm{x} \\
94^{\circ} \mathrm{C} \\
30 \mathrm{sec} \\
\\
{53^{\circ} \mathrm{C}} \\
1 \mathrm{~min} \\
30 \mathrm{x} \\
\\
7^{\circ} \mathrm{C} \\
1 \mathrm{~min} \\
\end{array}$ & $\begin{array}{c}\text { Jeng, } \\
\text { et.al., } 2003\end{array}$ \\
\hline
\end{tabular}

incubated at $37^{\circ} \mathrm{C}$ for $24 \mathrm{hrs}$.

\section{Detection of sortase A enzyme by PCR:}

Sortase A enzymes is detected by specific PCR primers. It was observed that sortase A was found in all GBS strains as

\section{$\begin{array}{llllllll}\text { Ladder } & 1 & 2 & 3 & 4 & 5 & 6 & 7\end{array}$}

which found that nearly all Streptococcus strains especially $S t$.agalactiae and $S t$.

500 bpyogens have sortase A.

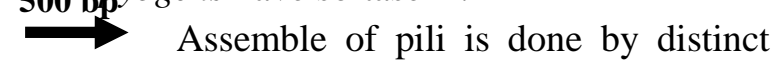
mechanism in Streptococcus agalactiae and most other Gram positive bacteria, these mechanism including a trans peptidase called sortase.

On the other hand, it was found that sortase A enzyme existed in all GBS isolates, this outcome may prove that sortase A is a housekeeping enzyme concerned with information of pili type sortase and anchors pili to the cell wall [13]. 


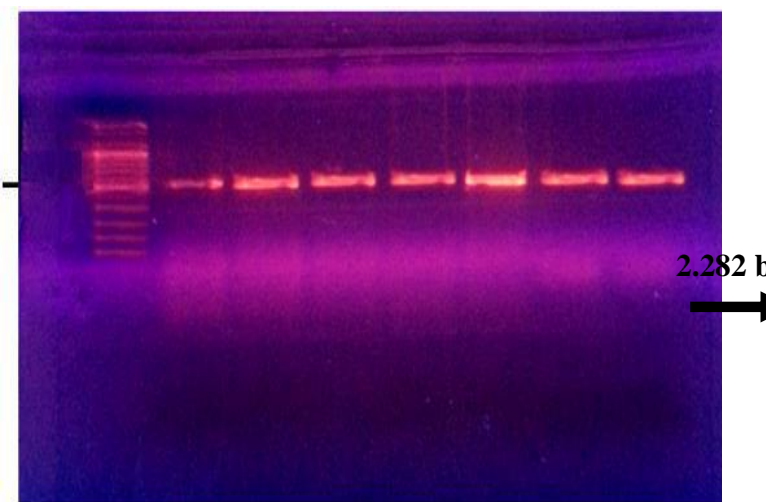

Figure (1) Gel electrophoresis of PCR products of sortase (A)

$*(1,2,3,4,5,6,7)$ GBS isolates with positive result for sortase $A$

This results agrees with the results obtained by [ who found that Srt A is present as a housekeeping in all GBS isolates.

\section{Detection of CovR/S in all isolates of} S. agalactiae:

CovR/S enzymes are detected by specific PCR primers. It was found that CovR/S was observed in tow isolates of GBS strains as show in Figure (2).

Although this gene is regulatory one and is responsible for regulation many virulence genes, it was found that tow isolates possesses it and this may explain that it is not ubiquitous, and the bacteria may have another regulatory genes that may have the same function of $\mathrm{Cov} R / \mathrm{S}$.

However, the results obtained in this study indicate the absence of $\operatorname{Cov} \mathrm{R} / \mathrm{S}$ maker from most isolates and this may because of high rate mutation of this gene in GBS as mentioned by Sendi [15] who found that mutation in Cov $\mathrm{R}$ may reduce the virulence of this bacteria.

Sendi [15] found that isolates of GBS bacteria recovered from patients with TSS (toxic shock syndrome) exhibited phenotypically hyper-hemolytic, which was caused by derepression of $C y l E$ due to CovR mutations.

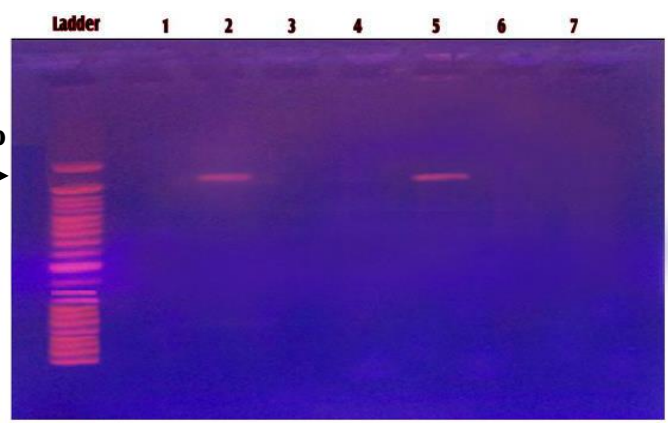

Figure (2) Gel electrophoresis of PCR products of $\mathrm{Cov} R / S$

$*(1,3,4,6)$ GBS isolates with negative result.

$*(2,5)$ GBS isolate with positive result for $\operatorname{Cov} R / S$.

\section{Detection of Colonization Factor Antigen (CFA/1):}

The production of colonization factor antigens type 1 (CFA/I ) were tested for all isolates and the results show that all strains have the ability to produce CFA/ 1 in the existence of D-mannose and with or without Vancomycin table (3).

Table (3) Bacterial adherence in the existence of D-mannose and Vancomysin.

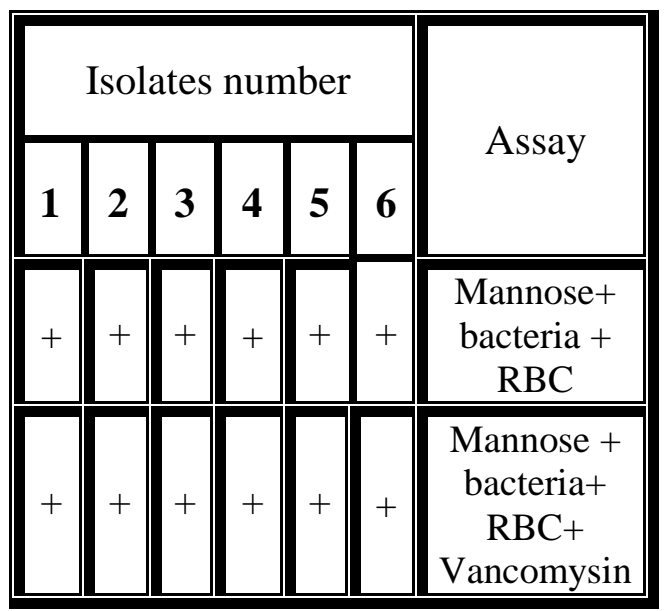

Mannose + bacteria $+\mathrm{RBC}=+\mathrm{ve}$ 
this means mannose resistance hemeagglutinin (MRHA).

Mannose + bacteria $+\mathrm{RBC}+\mathrm{Vancomysin}=$ +ve

this means mannose resistance hemeagglutinin with this antibiotic (MRHA +van).

The results of this study reveal that all isolates $(100 \%)$ of GBS that have been isolated from vagina have the ability to express the colonization factor antigens (CFA/I).

This factor is regarded as a fundimental factor that causes attachment of bacteria to cell targeted in the host, and their presence point to the existence of cell surface fimbrial antigens in the bacteria.

A similar pilus structure has also been identified in GAS, and as in $S$. agalactiae pili seem to be created by protein of a sortase-mediated covalent polymerization having the LPXTG motif and fusion of accessory proteins to the pilus backbone [16].

Sheen [17] reported that Streptococcus agalactiae has shown the ability to adhere and to invade vaginal epithelial tissue .

Adherence of GBS and its invasion were shown in both tissue culture and whole organism infection. Attachment to the extracellular matrix is consider an essential factor in the creation of disease and it is worthy to note that the highly virulent clones demonstrate improved attachment features, due to a union of a unique surface protein [18].

\section{Detection of Hemolysin:}

In this study, all Streptococcus agalactiae isolates were identified according to their ability to produce $\beta$ hemolysis on human blood agar and it is known that GBS produces narrow zone of hemolysis which may confer the diagnosis of this bacteria.
The ability of GBS isolates to produce hemolysin in the existence of Vancomysin were studied. It was found that there was no hemolysis in the presence of Van (except for one isolate), this will give good sign for this antibiotic to reduce the ability of this bacteria to obtain iron from environment.

However, in this study, all GBS were positive for $\beta$-hemolysin in absence of Vancomysin, as demonstrated in table (4).

Table (4) Bacterial hemolysis in the presence and absence of Vancomysin.

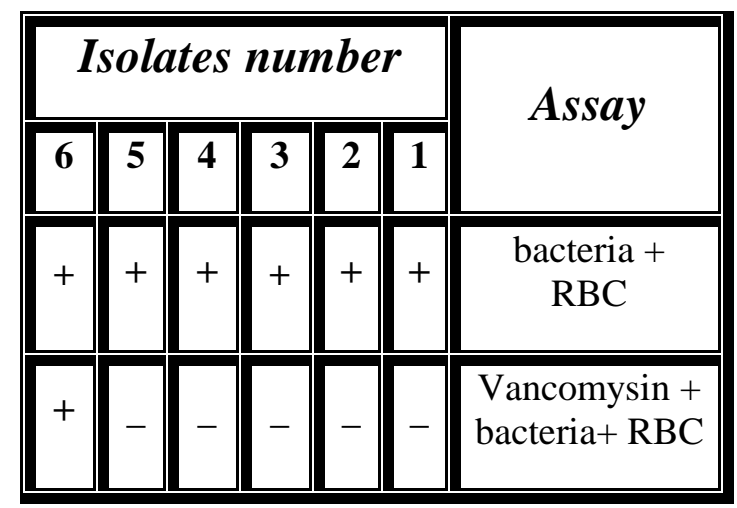

These results are nearly a like with the results obtained by Nizet [19] who found that a hallmark of the S.agalactiae phenotype is the appearance of $\beta$ hemolysis surrounding colonies growing on a plate of blood agar.

It's known that Hly is one of the most essential factors for identification of GBS which is characterized by It's being narrow zone of hemolysis on blood agar.

The mechanism by which GBS is capable of growing in limited iron is still to be characterized, since strains of GBS can grow in conditions of low iron and keep acceptable levels of cytoplasmic iron.

However, study of GBS genome shows two NRAMP (Natural ResistanceAssociated Macrophage Protein) transporters which pump iron or 
manganese into the bacterial cell as well as homologues of iron transport and uptake [20].

\section{Reference:}

1- Yang MJ, Sun PL, Wen KC, et al. Prevalence of maternal group $B$ streptococcus colonization and vertical transmission in low-risk women in a single institute. J Chinese Med Ass. 2012;75:258.

2- Melin, P. 2011. Neonatal group B streptococcal disease: from pathogenesis to preventive strategies. Clinical Microbiology and Infection, 17, no-no

3- Johri, A. K., L. C. Paoletti, P. Glaser, M. Dua, P. K. Sharma, G. Grandi, and R. Rappuoli. 2006. Group B Streptococcus: global incidence and vaccine development. Nat. Rev. Microbiol. 4:932-942

4- Barnett, T. C., and J. R. Scott. 2002. Differential Recognition of Surface Proteins in Streptococcus pyogenes by Two Sortase Gene Homologs. J. Bacteriol. 184:2181-2191.

5- Jiang, S. M., Ishmael, N., Hotopp, J. D., Puliti, M., Tissi, L., Kumar, N., Cieslewicz, M. J., Tettelin, H. \& Wessels, M. R. 2008. Variation in the group B Streptococcus CsrRS regulon and effects on pathogenicity. Journal of Bacteriology, 190, 1956-1965.

6- Nobbs AH, Lamont RJ, Jenkinson HF (2009) Streptococcus adherence and colonization. Microbiol Mol Biol Rev 73: 407-450.

7- McFadden, J. F. (2000). Biochemical tests for the identification of medical bacteria. 3rd Ed. The Williams and Wilkins- Baltimor, USA.
8- Forbes, B. A., Daniel, F. S. and Alice, S. W. (2007). Baily and Scott's Diagnostic microbiology. 12thed. Mosby. Elsevier Company, USA.

9- Sambrook, J. and Russell, D.W. (2001). Molecular cloning: A laboratory manual, $3^{\text {rd }}$. ed., Cold Spring Harbor Laboratory Press. Cold Spring Harbor. NY. USA.

10- Cruickshank, R., Duguid, J. P., Marmion, B. P., andSwain, R. H. A. (1973). Medical Microbiology, 12thed., Vol. I. Churchill Livingstone, Edinburgh.

11- De Boy, J., K. Wachsumth and B. Davis. 1980. Hemolysin activity in enterotoxigenic and non- enterotoxigenic strains of E. coli. J. Clin. Microbiol.12:193-198.

12- Lamees , A. 2003. Isolation and Characterization of Streptococcus agalactiae from Woman Patients with Vaginitis in Hilla Province. MSC. Thesis. Collage of Medicine. Babylon University.

13- Mandlik A, Swierczynski A, Das A, Ton-That H (2008) Pili in Gram-positive bacteria: assembly, involvement in colonization and biofilm development. Trends Microbiol 16: 33-40.

14- Nobbs AH, Rosini R, Rinaudo CD, Maione D, Grandi G, et al. (2008) Sortase A utilizes an ancillary protein anchor for efficient cell wall anchoring of pili in Streptococcus agalactiae. Infect Immun 76: 3550-3560.

15- Sendi, P., Johansson, L., Dahesh, S., Van-Sorge, N. M., Darenberg, J., Norgren, M., Sjolin, J., Nizet, V. \& Norrby-Teglund, A. 2009. Bacterial phenotype variants in group B streptococcal toxic shock syndrome. Emerging Infectious diseases, 15, 223-32. 
16- Dramsi, S., Caliot, E., Bonne, I., Guadagnini, S., Prevost, M.-C., Kojadinovic, M., Lalioui, L., Poyart, C. \& Trieu-Cuot, P. 2006. Assembly and role of pili in group B streptococci. Molecular Microbiology, 60, 1401-1413.

17- Sheen, T. R., Jimenez, A., Wang, N.Y., Banerjee, A., Van Sorge, N. M. \& Doran, K. S. 2011. Serine-rich repeat proteins and pili promote Streptococcus agalactiae colonization of the vaginal tract. Journal of Bacteriology, 193, 6834-6842.

18- Tazi, A., Disson, O., Bellais, S., Bouaboud, A., Dmytruk, N., Dramsi, S., Mistou, M.-Y., Khun, H., Mechler, C., Tardieux, I., Trieu-Cuot, P., Lecuit, M. \& Poyart, C. 2010. The surface protein HvgA mediates group B Streptococcus hypervirulence and meningeal tropism in neonates. The Journal of Experimental Medicine, 207, 2313-2322.

19- Nizet, V., R.L. Gibson, E.Y.Chi, P.E. Framson, M. Hulse and C.E.Rubens. 1996. Group B Streptococcal betahemolysin expression is associated with injury of lung epithelial cells. Infect Immun. 64:3818-3826.

20- Tettelin T. et al., Proc. Natl. Acad. Sci. U.S.A. 99, 12391 (2002). 